\title{
Antibody anti-H5N1 detection in poultry farmers and workers in poultry collection facilities in Indonesia, 2007
} \author{
Krisna N. A. Pangesti, ${ }^{1}$ Fera Ibrahim ${ }^{2}$ \\ ${ }^{1}$ National Institute of Health Research and Development, Ministry of Health, Jakarta, Indonesia \\ ${ }^{2}$ Department of Microbiology, Faculty of Medicine, University of Indonesia, Jakarta, Indonesia \\ ${ }^{3}$ National Institute for Public Health and the Environment (RIVM), Bilthoven, The Netherlands
}

Vivi Setiawaty, ${ }^{1}$ Endang R. Sedyaningsih, ${ }^{1}$ Tjahyani M. Sudiro, ${ }^{2}$ Mirna Robert - Du R. van Beest Holle, ${ }^{3}$

\begin{abstract}
Abstrak
Tujuan Sejak bulan Juli 2005 sampai Mei 2008, Indonesia melaporkan 133 kasus manusia konfirm H5N1 dengan case fatality proportion $81 \%$. Lima puluh empat persen kasus mempunyai riwayat kontak langsung dengan unggas (ayam). Oleh sebab itu, penting untuk mengetahui adanya antibodi anti H5N1 diantara orang yang mempunyai kontak erat dengan unggas yang terpapar virus H5N1.

Metode Pada penelitian ini, sera diambil dari pekerja yang sehat ditempat pengumpul ayam (TPnA) di Jakarta dan peternak unggas yang sehat di Sukabumi yang kontak erat dengan unggas. Antibodi anti H5N1 diuji dengan tehnik Hambatan Hemagglutinasi (HI) yang dimodifikasi menggunakan antigen A/Ck/Banten/05-1116/05(H5N1) dan dengan tehnik Virus Neutralisasi (NT) menggunakan virus A/H5N1/Indo/05/IBCDC-RG.

Hasil Dari 216 sera pekerja TPnA dan sera 495 peternak yang dikumpulkan, kami temukan bahwa seluruh peternak seronegatif dan satu persen dari pekerja TPnA seropositif dengan dua uji HI dan NT.

Kesimpulan Penelitian ini mendeteksi kemungkinan adanya infeksi virus H5N1 yang tanpa gejala diantara pekerja di TPnA yang berkontak erat dengan berbagai asal unggas yang berbeda-beda dan terlihat dengan adanya titer antibodi yang berbeda, namun tidak ada satupun peternak yang mempunyai titer antibodi. (Med J Indones 2010; 19:124-9)
\end{abstract}

\begin{abstract}
Aim Between July 2005 and May 2008, Indonesia reported 133 H5N1 confirmed human cases with a case fatality proportion of $81 \%$. Fifty-four percent of cases had a history of direct contact with poultry (chickens). Therefore, it is important to define the detection of antibody of $\mathrm{H} 5 \mathrm{~N} 1$ among people who have intensive contact with poultry have been exposed to $\mathrm{H} 5 \mathrm{~N} 1$ viruses.

Methods We collected sera from healthy poultry-collecting-facility (PCF) workers in Jakarta and healthy poultryfarmers in Sukabumi which have close contact with poultry. Anti-H5N1 antibodies were tested with modified Haemagglutination Inhibition (HI) assay using A/Ck/Banten/05-1116/05(H5N1) antigen and with Neutralization (NT) assay using $\mathrm{A} / \mathrm{H} 5 \mathrm{~N} 1 / \mathrm{Indo} / 05 / \mathrm{IBCDC}-\mathrm{RG}$ virus.

Results Among the 216 PCF worker sera and the 495 poultry-farmer sera that we collected, we found that all poultryfarmers were seronegative and one percent of poultry-collecting-facilities workers were seropositive by both $\mathrm{HI}$ and $1 \%$ by NT assays.

Conclusions This study detected asymptomatic H5N1 virus infection among poultry workers in PCFs with intensive contact with various types of different poultry who had different titers of antibody, but no antibodies were detected among poultry farmers. (Med $J$ Indones 2010; 19:124-9)
\end{abstract}

Key words: Avian influenza, farmers, poultry workers, seropositive

The epidemic of virus A (H5N1) among poultry was for the first time reported in Indonesia in late 2003. Until recently, 31 out of the 33 provinces have reported outbreaks of $\mathrm{H} 5 \mathrm{~N} 1$ in poultry at least once. ${ }^{1}$ Among humans, H5N1 infection in Indonesia was first reported in a family cluster in Tangerang in July 2005, and until May 2008 there were 133 H5N1 confirmed human cases with 108 fatalities. ${ }^{2}$ Other studies have reported that the main risk factor for virus $\mathrm{A}(\mathrm{H} 5 \mathrm{~N} 1)$ infection was contact with sick or dead poultry, including handling or having sick poultry in the neighbourhood., ${ }^{3,4} \mathrm{~A}$ study of poultry farmers in areas affected with avian influenza $\mathrm{A}$ (H5N1) epidemics in Hong Kong in 1997-1998 found that $10 \%$ of this population had an increase of titers of antibody against influenza virus A (H5N1) with microneutralization test. ${ }^{3}$

Serological methods to diagnose viral infection by detecting its antibody include hemagglutination 
inhibition test (HI), viral neutralization test and ELISA (Enzyme-linked immunosorbent assay). Viral neutralization test is very sensitive and specific for detecting specific antibody against avian influenza A/ $\mathrm{H} 5 \mathrm{~N} 1 \mathrm{in}$ animals and humans. This test is able to detect a low titer of antibody that may not be detected by traditional $\mathrm{HI}$ assay. ${ }^{6}$ However, the viral neutralization test for virus A (H5N1) needs to be conducted in a laboratory that has Biosafety level-3 (BSL-3) facilities. On the other hand, HI assay can be conducted in BSL-2 laboratories; it also has a relatively easy working procedure, and does not require long to obtain the results. Its sensitivity is relatively good when comparing it with NT test as a gold standard. ${ }^{6}$ Until now, ELISA is not an alternative test for detecting antibody against virus A (H5N1), since its sensitivity and specificity are low. ${ }^{6}$

We conducted a study among poultry farmers in Sukabumi, West Java Province, and workers in poultrycollecting-facilities (PCF) in Jakarta, the biggest city in Indonesia. The aim of this study is to define the detection of antibody of H5N1 among high risk people who have close contact with poultry. In farms, the farmers breed the poultry, and after several days they will sell it to the PCF. Thousands of various types of poultry arrive from the farms in the countryside to PCFs everyday and from there they are transported to wet markets or slaughterhouses where they are to be sold to consumers. The present study was part of a project, which also included investigation of risk factors and perceived symptoms using questionnaires. Results of those studies among poultry farmers and poultry workers will be reported elsewhere.

\section{METHODS}

\section{Sera}

The study was conducted among healthy workers in 34 poultry-collecting-fascilities in five areas in Jakarta province and healthy poultry farmers in Sukabumi, in January and April 2007. Sera were taken from 216 PCF workers and 495 farmers who volunteered to participate in the study and signed an informed consent form. Sera were kept in $-80{ }^{\circ} \mathrm{C}$ before tested with modified $\mathrm{HI}$ and NT assays. Just before the tests, receptor destroying enzyme (RDE) was added to the sera and then they were=kept at $37{ }^{\circ} \mathrm{C}$ for 18 hours, followed by $56{ }^{\circ} \mathrm{C}$ for 30 minutes. $^{7}$

\section{Influenza A (H5N1) viruses, antigens and MDCK cells}

We used influenza virus strain A/H5N1/Indo/05/2005/ IBCDC-RG for the NT test. This strain is a reversed genetic ( $R G)$ form of an Indonesian strain influenza A virus, developed by the CDC, Atlanta. Influenza virus $\mathrm{A} / \mathrm{Indonesia} / 5 / 05$ was detected from one of the first human cases in Indonesia in 2005..$^{7}$ These viruses were cultured in embryonated eggs aged 10 days ${ }^{6,7}$ in the BSL-3 laboratory of NIID (National Institute of Infectious Diseases), Tokyo, Japan. Stocks of viruses were kept in $-80{ }^{\circ} \mathrm{C}$.

For the HI assay, we used antigen originated from viruses which were isolated from infected chickens in 2005, A/Ck/Banten/05-1116/05 (H5N1). These antigens were produced by the Institute of Veterinary Research (Balitvet), Department of Agriculture, Indonesia.

For the NT test, we used the $5^{\text {th }}$ passages of MDCK cells in NIID laboratory, Tokyo. We put $1.5 \times 10^{4}$ cells/ well in a 96 well plate with flat bottom and cultured them for three days in $5 \% \mathrm{CO} 2$ incubators, at $37^{\circ} \mathrm{C}$. The medium used for cell cultures was MEM (Minimum Essential Medium), with additions of $10 \%$ Fetal Calf Serum (FCS) and 100 unit/ml Penicillin-Streptomycin. The $50 \%$ tissue culture infectious dose $\left(\mathrm{TCID}_{50}\right)$ was determined by adding $1 / 2 \log$ diluted virus in MDCK cells to find out the dilution of the virus stock needed for the NT test. ${ }^{7}$

\section{Haemagglutination Inhibition Test}

We used $1 \%$ horse red blood cells for the HI tests, ${ }^{8}$ with $8 \mathrm{HAU} / 50 \mu \mathrm{l}(4 \mathrm{HAU} / 25 \mu \mathrm{l})$ antigen concentration. ${ }^{7}$ The results were considered positive if the anti A (H5N1) antibody titer was equal or more than $160 .^{9}$

\section{Viral Neutralization Test}

Two-fold dilutions of sera were put into a flat bottom 96 well plate, and $100 \mathrm{TCID}_{50} / 50 \mu 1$ viruses were added. At the same plate, four wells were used for control viruses and the other four wells were used for control cells. The plate was incubated for 30 minutes at $37^{\circ} \mathrm{C}$, in $5 \% \mathrm{CO}_{2}$. Subsequently, $100 \mu 1$ of mixed sera and virus was inoculated into a flat bottom 96 well plate containing MDCK cells. The plate was incubated for 3 days at $37^{\circ} \mathrm{C}$, in $5 \% \mathrm{CO}_{2}$ On the fourth day, viruses were washed and inactivated, cells were stained by Naphtalene Blue Black. Reading of optical density 
(OD) was done using a plate reader at $\lambda 630 \mathrm{~nm}$. The appearance of a Cythopatic Effect (CPE) determined positive results with OD values equal or less than the average virus control value. Using the WHO cut-offpoint value, the NT test was considered positive when the $\mathrm{H} 5 \mathrm{~N} 1$ antibody titer was equal or more than $80 .{ }^{3,6,9}$

\section{Analyses of homological nucleotides and amino acid of HA-H5N1 gen}

Homological data analyses were conducted using Genetyx-Win MFC Application version 5.1.1.0. (Software development, Tokyo, Japan). Nucleotide sequences were downloaded from NCBI, Database, Influenza virus resources, and we used only data of viruses originated from 2003 and 2005 chicken from certain geographic areas where chicken in the collector houses were brought from, i.e., Central and West Java provinces, and data of viruses originated from 2005 and 2007 patients reported from Banten province. ${ }^{10}$

\section{RESULTS}

Modified HI test with antigen A/Ck/Banten/05-1116/05 (H5N1) (Balitvet) gave titer values with an overall range of 10 to 320 where 53 out of 216 sera (24.5 $\%$ ) showed titer for PCF workers and no HI titers for farmers (Table 1). Based on previous studies, HI test was considered positive when the anti $\mathrm{A}(\mathrm{H} 5 \mathrm{~N} 1)$ antibody titer was equal or more than 160 and for NT test, we used titers equal or more than 80 as a cut-off-point value for antibody based on the WHO criteria and a study conducted by Thomas Rowe in $1999 .{ }^{6,9}$ Our study revealed that only two out of the 216 PCF workers' sera (1\%) were positive by both HI and NT tests and none of the farmers showed positive antibodies with NT testing. (Table 1)

We did not find any difference when comparing results of the neutralization test using reversed genetic A/ Indonesia/5/05 virus with results using $\mathrm{A} /$ Indonesia/5/05 virus (data not shown).

The distribution of antibody titer from PCF workers by NT and Horse HI assays are shown in figure 1.

Comparison of modified HI and NT test results from PCF's workers are shown in table 2.

Table 1. Results of modified HI and NT tests for PCF workers and farmers

\begin{tabular}{|c|c|c|c|c|c|}
\hline \multirow[b]{2}{*}{ No. } & \multirow[b]{2}{*}{$\begin{array}{c}\text { Anti A(H5N1) antibody titer with } \mathrm{HI} \\
\text { and NT tests }\end{array}$} & \multicolumn{2}{|c|}{ Modified HI test* } & \multicolumn{2}{|c|}{ NT test** } \\
\hline & & $\begin{array}{l}\text { PCF workers } \\
(\mathrm{N}=216) \\
\Sigma(\%)\end{array}$ & $\begin{array}{c}\text { Farmers } \\
(\mathrm{N}=495) \\
\Sigma(\%)\end{array}$ & $\begin{array}{c}\text { PCF workers } \\
(\mathrm{N}=216) \\
\Sigma(\%)\end{array}$ & $\begin{array}{c}\text { Farmers } \\
(\mathrm{N}=495) \\
\Sigma(\%)\end{array}$ \\
\hline 1. & $<10$ & $163(75.5)$ & $495(100 \%)$ & $127(58.8)$ & $494(99.8)$ \\
\hline 2. & 10 & $10(4.6)$ & 0 & $22(10.2)$ & 0 \\
\hline 3. & 20 & $12(5.6)$ & 0 & $20(9.3)$ & $1(0.2)$ \\
\hline 4. & 40 & $16(7.4)$ & 0 & $21(9.7)$ & 0 \\
\hline 5. & 80 & $13(6)$ & 0 & $17(7.9)$ & 0 \\
\hline 6. & 160 & $1(0.5)$ & 0 & $7(3.2)$ & 0 \\
\hline \multirow[t]{2}{*}{7.} & 320 & $1(0.5)$ & 0 & $2(0.9)$ & 0 \\
\hline & & $2(1)^{(a)}$ & $0^{(\mathrm{a})}$ & $26(12)^{(b)}$ & $0^{(\mathrm{b})}$ \\
\hline
\end{tabular}

* using antigen $\mathrm{A} / \mathrm{Ck} / \mathrm{Banten} / 05-1116 / 05$ (H5N1)-Balitvet

** using $\mathrm{A} / \mathrm{H} 5 \mathrm{~N} 1 / \mathrm{Indo} / 05 / \mathrm{IBCDC}-\mathrm{RG}$ virus

(a) Sera with titer $\geq 160$

(b) Sera with titer $\geq 80$

All titers were presented representative of duplicate assays 


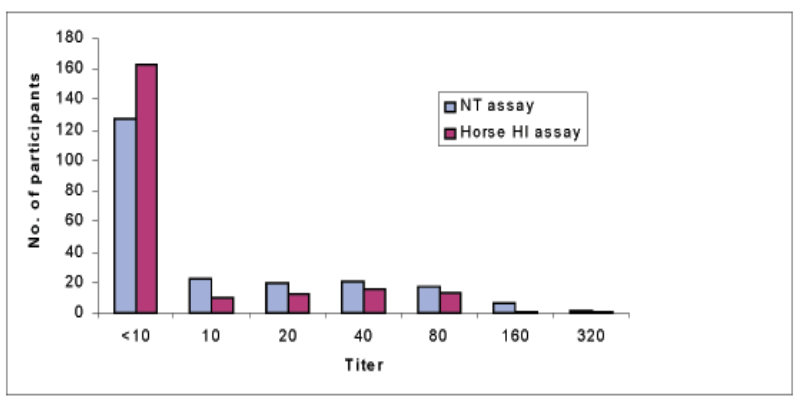

Figure 1. Distribution of antibody titer of NT and HI assays

Table 2. Comparison of modified HI with NT test results

\begin{tabular}{llll}
\hline & NT positive $(\geq 80)$ & NT negative $(<80)$ & Total \\
\hline HI positive $(\geq 160)$ & 2 & 0 & 2 \\
HI negative $(<160)$ & 24 & 190 & 214 \\
Total & 26 & 190 & 216 \\
\hline
\end{tabular}

We also performed nucleotide and amino acid homological analyses of HA genes of influenza $\mathrm{A} / \mathrm{H} 5 \mathrm{~N} 1$ virus originating from chickens in 2003, 2005, 2007 and humans in 2005,2007 . The results ranged from 95.9 to $100 \%$ and 96.5 to $99.6 \%$, respectively. ${ }^{10}$

Immunogenecity epitope analysis of specific amino acid HA-H5 at the $151-160^{11,12}$ position showed an A156T change in viruses isolated from chickens and humans in 2005 and 2007 (A/ck/Purworejo/BBVW/2005, A/ck/ wates130/2005, A/ck/Magelang1631-57/2007, A/ck/ Semerang1631-62/2007, A/Indonesia/CDC1046/2007, A/Indonesia5/2005, A/Indonesia7/2005), as compared to viruses isolated from chicken in 2003 (A/ck/ Indonesia/11/2003 and $\mathrm{A} / \mathrm{ck} /$ Indonesia/7/2003). ${ }^{10}$

When we tried to perform homological analyses of the HA gene amino acid of influenza virus $\mathrm{A} /$ Indonesia/5/05 with influenza virus $\mathrm{A} / \mathrm{H} 3 \mathrm{~N} 2$ strain $\mathrm{A} /$ Thailand/ CU124/2006 and A/H1N1 A/Thailand/CU32/2006, the results showed a different sequence of amino acid.

\section{DISCUSSION}

Our study found no seropositivity against influenza virus A(H5N1) among poultry farmers in Sukabumi, although we found low seropositivity among PCF workers, as compared to the result found by Trang et al. in Vietnam in 2007. Trang et al. had conducted a study among chicken poultry workers in three provinces where human cases of avian influenza $\mathrm{A}(\mathrm{H} 5 \mathrm{~N} 1)$ had been reported. The anti $\mathrm{A}(\mathrm{H} 5 \mathrm{~N} 1)$ antibody had been tested with $\mathrm{HI}$ test using A/Ck/Vietnam/6/03 (H5N1) antigen, confirmed with microneutralization (MN) test using NIBRG-14 virus (A/Vietnam/1203/04(H5N1$R G)$ ). They had shown $4.7 \%$ of the workers were seropositive. ${ }^{13}$

We assumed that the present of antibody titer was due to the difference of the risks of the study subjects. In our study among farmers in Sukabumi, sera were taken from people who work in the farm where they breed their chickens, and in PCFs in Jakarta where they are exposed to different chicken flocks from different areas every day. Hence, the risk of PCF workers was higher as compared to the risk faced by poultry farmers.

It is already well known that influenza virus A continues to evolve, especially the surface genes, Hemagglutinin (HA) and Neuraminidase (NA), and that there is a possibility that they are not recognized by the host immune response. ${ }^{14,15} \mathrm{We}$ had been aware of the fact that the avian influenza $\mathrm{A}(\mathrm{H} 5 \mathrm{~N} 1)$ virus, that had started the epidemics in chickens in 2003 in Indonesia, might have evolved, and the avian influenza A(H5N1) viruses which caused poultry deaths in 2005 showed changes in some of the amino acid positions, especially in the epitope. ${ }^{16}$

The position of the amino acid epitope in the HA gene of influenza virus $\mathrm{A} / \mathrm{H} 5 \mathrm{~N} 1$ isolated from humans and chickens in 2005 and 2007 were different as compared to those isolated from chickens in 2003, i.e., T156A. However, this amino acid epitope position was still similar in the HA gene of influenza virus $\mathrm{A} / \mathrm{H} 5 \mathrm{~N} 1$ isolated from humans and chickens in 2005 and 2007.

Until recently, the NT test is still considered the gold standard for detecting anti $\mathrm{A}(\mathrm{H} 5 \mathrm{~N} 1)$ antibody in humans. NT testing has some drawbacks, e.g., the cost is relatively high since it uses MDCK cells and needs to be conducted in a BSL-3 laboratory if highly pathogenic avian influenza viruses are used, it requires a relatively long time to obtain a result - approximately 4 days to wait for the appearance of CPE in MDCK cells, and it requires special skills. ${ }^{17} \mathrm{We}$ used A/H5N1/Indo/05/IBCDC-RG for the NT test since it was developed from virus isolated the same year with the viral antigens used for $\mathrm{HI}$ tests.

Our study showed a significant agreement between results of the HI and NT tests. There were 190 negative sera with the HI test that were also negative with the NT test, but there were 24 negative sera with $\mathrm{HI}$ test that were positive by NT test. This may have been caused by 
the low antibody titers, which failed to be detected by the $\mathrm{HI}$ test, but viral amplification in NT tests has allowed the results to be detected. ${ }^{18,19}$ Although the specificity of HI test $100 \%$ but The sensitivity of the HI test (only $7.7 \%$, as compared to the NT test as gold standard) did not confirm that this test is a good alternative to detect host immune response against avian influenza. The HI test requires simple techniques, it takes one day to obtain results, the test is relatively cheap, and can be conducted in a BSL-2 laboratory. This HI test is also used to determine the antigenic characteristics of different strains of seasonal influenza viruses. ${ }^{18,19}$

The detection of anti $\mathrm{A}(\mathrm{H} 5 \mathrm{~N} 1)$ antibody in the poultrycollecting-facility workers showed that they have been exposed to influenza virus $\mathrm{A} / \mathrm{H} 5 \mathrm{~N} 1$, although none of them reported symptoms. We assumed that this was caused by gradual exposures with influenza virus $\mathrm{A}(\mathrm{H} 5 \mathrm{~N} 1)$ with somewhat lower pathogenicity, high enough to induce an antibody response but not high enough to cause clinical symptoms. ${ }^{3,18,19} \mathrm{We}$ found different results in farmers. We did not detect antibody anti $\mathrm{H} 5 \mathrm{~N} 1$ in this population since the farmers had less contact with different types of poultry compared to PCF workers.

The homology levels of influenza virus A/chicken/ Indonesia/7/2003(H5N1) and A/ck/Purworejo/BBVW /2005 (H5N1) with A/Indonesia/CDC1046/2007 (H5N1) were $96.6 \%$ and $97 \%$, respectively. This indicated that virus $\mathrm{A}(\mathrm{H} 5 \mathrm{~N} 1)$ isolated from humans in 2007 was more similar to virus $\mathrm{A}(\mathrm{H} 5 \mathrm{~N} 1)$ isolated from chickens in 2005 than that isolated in 2003. Therefore, this also explained that the 2005 antigen was still appropriate for our HI test.

The specific immunogenicity of HA-H5 is related to the amino acids in positions $36,83,86,120,140,155$, $156,162,183,189,212,223$ and $263 . .^{11,12}$ However, only amino acid in position 156 showed a difference between viruses from 2003 as compared to 2005 and 2007, i.e., Alanin (A) was changed to Threonin (T). Apparently this change has caused differences in the result of the HI test, as also previously mentioned by Hoffman et al, 2005 . But since there were no differences between viruses of 2005 and 2007, we can still use virus of 2005 to detect antibody anti H5N1 from sera that were taken in 2007.

The possibility that our results were caused by a crossreactivity with anti $\mathrm{H} 1$ and $\mathrm{H} 3$ antibody was very small, since the sequence of amino acid of the HA gene of $\mathrm{H} 5$ was very different from the sequence of amino acid of the HA gene of $\mathrm{H} 1$ and $\mathrm{H} 3$. This fact has been demonstrated by a Govorkova et al, 2006 i.e., giving virus $\mathrm{A} / \mathrm{HK} / 213 / 03-\mathrm{RG}$ (H5N1) vaccination to ferrets that already developed anti-H3 antibody did not influence the development of anti-H5 antibody, since the HA protein of $\mathrm{H} 3$ is different than that of $\mathrm{H} 5 .^{(20)}$

In conclusion, our study showed different results in antibody detection among poultry farmers and PCF workers. We detected that $1 \%$ of the PCF workers in Jakarta developed anti A(H5N1) antibody with the HI test using A/ck/Banten/05-1116/05 (H5N1) antigen, confirmed with the NT test using A/Indo/05/H5N1/ IBCDC-RG virus. However, we did not detect antibody anti H5N1 among poultry farmers. The different results may be due to different exposures between these two populations. Although there were no epitope differences between the 2005 and 2007 virus, it is still important to utilize antigen from the same year as the year of the tested sera. Besides, it may also be important to utilize antigen from viruses taken from the same geographical areas, as where the sera were taken.

\section{Acknowledgments}

We would like to thank RIVM, The Netherlands, and JICA for their financial support for these studies. We really appreciate the help of CDC Atlanta, Georgia, USA, and the National Institute for Veterinary Research, MOA of the Republic of Indonesia, for providing the reversed genetic virus and antigens. Special thanks went to Dr. Ruben Donis, PhD, CDC Atlanta, Georgia, USA. We thank to our many colleagues at the Directorate General of Disease Control and Environment Health and National Institute of Health Research and Development, Ministry of Health, Jakarta, Indonesia; provincial and district health livestock offices at Indonesia and especially to Shigeyuki Itamura, $\mathrm{PhD}$ at National Institute of Infectious Disease, Murayama, Tokyo, Japan for their contributions to our laboratory investigations.

\section{REFERENCES}

1. Ministry of Agriculture, Directorate General of Animal Husbandary. (2006) Epidemiology of avian influenza in poultry in Indonesia.

2. Ministry of Health, Center for Public Communication. One more bird flu patient. Available at http://www.depkes.go.id/ index.php. Accessed 28 May 2008

3. Bridges CB, Lim W, Primer JH, Sims L, Fukuda K, Mak $\mathrm{KH}$, et al. Risk of influenza A (H5N1) infection among poultry workers, Hong Kong, 1997-1998. J Infect Dis. 2002; 185:1005-10. 
4. Sedyaningsih ER, Isfandari S, Setiawaty V, Rif'ati L, Harun S, Purba W, et al. Epidemiology of cases of H5N1 virus infection in Indonesia, July 2005 - June 2006. J Infect Dis. 2007; 196(4):522-7.

5. Dinh PN, Hoang TL, Nguyen Thi KT, Nguyen TH, Le Thi QM, Le HP, et al. Risk factor for human infection with avian influenza A H5N1, Vietnam, 2004. Emerg Infect Dis. 2006; 12(12):1841-7.

6. Rowe T, Abernathy RA, Hu-Primmer J, Thompson WW, Lu X, Lim W, et al. Detection of antibody to Avian Influenza A (H5N1) virus in human serum by using a combination of serological assays. J of Clin Microbiol. 1999; 37(4):937-43.

7. World Health Organization Global Influenza Programme. (2002) WHO manual on animal influenza diagnosis and surveillance.Available at: http://www.who.int/csr/resources/ publications/influenza/WHO_CDS_CSR_NCS_2002_5/en/ print.html. Accessed 30 September 2007.

8. Stephenson I, Wood JM, Nicholson KG, Zambon MC. Sialic Acid Receptor specificity on erythrocytes affects detection of antibody to avian influenza haemagglutinin. J Med Virology. 2003; 70:391-8.

9. WHO case definitions for human infections with influenza A(H5N1) virus, 26 August 2006. Available at : www. who.int/csr/disease/avian_influenza/guidelines/case_ definition2006_08_29/en. Accessed 30 September 2007.

10. Setiawaty V, Sudiro TM, Ibrahim F, Pangesti KNA, Itamura S, Sedyaningsih ER. Deteksi Antibodi Anti H5N1 dengan Uji Hambatan Hemagglutinasi dan Netralisasi. Journal of Respirology 2009; 29(1):11-7.

11. Class ECJ, Osterhaus ADME, van Beek R, de Jong JC, Rimmelzwaan GF, Senne DA, et al. Human influenza A H5N1 virus related to a highly pathogenic avian influenza virus. Lancet. 1998; 351:472-7.
12. Hoffmann E, Lipatov AS, Webby RJ, Govorkova EA, Webster RG. Role of specific hemagglutinin amino acids in the immunogenicity and protection of $\mathrm{H} 5 \mathrm{~N} 1$ influenza virus vaccines. Proceeding of National Academy of Sciences 2005; 102(36): 12915-20.

13. Trang NV, Binh NH, Sao Mai TT, Van DT, Anh BN, Tuan $\mathrm{NN}$, et al. Detection of anti H5 antibodies in sera of H5N1 contact in Vietnam. Poster presentation in Avian Influenza Conference, 2007, Bangkok.

14. Sinya K, Hatta M, Yamada S, Takada A, Watanabe S, Halfmann P, Horimoto T, et al. Characterization of human H5N1 influenza A virus isolated in 2003. J of Virology. 2005; 79(15):9926-32.

15. Stevens J, Blixt O, Tumpey TM, Taubenberker JK, Paulson JC, Wilson IA. Structure and receptor specificity of the hemagglutinin from an $\mathrm{H} 5 \mathrm{~N} 1$ influenza virus. Science. 2006; 312:404-10.

16. Webster RG and Govorkova EA. H5N1 influenza continuing evolution and spread. N Engl J Med. 2006; 355(21):2174-7.

17. Hierholzer JC and Killington RA. Virus isolation and quantitation, In: B.W.J. Mahy and H.O. Kangro, editors. Virology Methods Manual. 1996; Academic Press: 25-46.

18. Subbarao K and Katz J. Avian influenza viruses infecting humans (review). Cellular and Molecular Life Sciences (CMLS). 2000; 57:1770-84

19. Katz JM, Lu X, Frace AM, Morken T, Zaki SR, Tumpey TM. Pathogenesis and immunity to avian influenza A H5 viruses. Biomed and Pharmacother. 2000; 54:178-87.

20. Govorkova EA, Webby RJ, Humberd J, Seiler JP, Webster RG. Immunization with reverse-genetics-produced H5N1 influenza vaccine protects ferrets againts homologous and heterologous challenge. J Infect Dis. 2006; 194:159-67. 